\title{
MODERN LAMINATE COMPOSITE DESIGNED FOR AIRCRAFT CONSTRUCTION
}

\author{
Izabela Korzec ${ }^{1 \Xi}$, Jacek Czarnigowski ${ }^{2}$, Tomasz $Ł u s i a k^{3}$, Daniel Rękas ${ }^{4}$, Mateusz Marciniak $^{5}$, Kamil $^{\prime}$ \\ Komajda ${ }^{6}$ \\ ${ }^{1 \Xi}$ mgr inż. Izabela Korzec: Politechnika Lubelska, Wydział Mechaniczny, Nadbystrzycka 36, 20-618 Lublin, \\ Polska, e-mail: ikorzec@wp.pl \\ ${ }^{2}$ dr hab. inż. Jacek Czarnigowski, prof. PL: Politechnika Lubelska, Wydział Mechaniczny, Katedra \\ Termodynamiki Mechaniki Płynów i Napędów Lotniczych, Nadbystrzycka 36, 20-618 Lublin, Polska, e-mail: \\ J.Czarnigowski@pollub.pl \\ ${ }^{3}$ dr inż. Tomasz Łusiak: Lotnicza Akademia Wojskowa, Wydział Lotnictwa, Katedra Płatowca i Silnika, Dywizjonu \\ 303, 08-521 Dęblin, Polska, , e-mail: t.lusiak@law.mil.pl \\ ${ }^{4}$ mgr inż. Daniel Rękas: Politechnika Lubelska, Wydział Mechaniczny, Nadbystrzycka 36, 20-618 Lublin, Polska, \\ e-mail:daniel.rekas@pollub.pl \\ ${ }^{5}$ mgr inż. Mateusz Marciniak : Politechnika Lubelska, Wydział Mechaniczny, Nadbystrzycka 36, 20-618 Lublin, \\ Polska, e-mail:marciniak.mateusz1995@gmail.com \\ ${ }^{6}$ mgr inż. Kamil Komajda: Politechnika Lubelska, Wydział Mechaniczny, Nadbystrzycka 36, 20-618 Lublin, \\ Polska, e-mail:Kamil.komajda@pollub.edu.pl
}

Submitted: 2019-Sep-06 / Accepted: 2019-mm-dd/ Published: 2019-mm-dd

\section{ABSTRACT}

The article presents modern laminate composites designed for aircraft structural elements based on ECC e461 symmetric fabric and Interglas 02037 symmetric fabric with MGS L285/H285 resin. These composites differ in the weave used and the type of fabric. The article presents basic strength parameters of the composite obtained as a result of stand tests. The results of compressive strength tests of the material samples are presented. It was shown that the weave of the fabric significantly affects the strength parameters of the composite. The change of the weave caused the increase in strength by more than $65 \%$. The possibilities of application of this material on selected structural elements of aircraft such as: propeller blade plating, masts, shavings, pylons.

KEYWORDS: Compressive stress tests, hand lamination, symmetrical fabrics ECC e461, Interglas 02037 resin.

\section{Introduction}

Aircraft structures in their construction use materials characterized by high strength and low weight. The main materials doing these requirements are aluminium alloys, titanium alloys and composite materials. Today, composite materials take over from aluminium alloys a key position in the aerospace industry. This is because composite materials have the best strength-to-weight ratio $[2,5,7]$. Composite materials commonly used in aircraft are based on a matrix made of: glass fibre, carbon fibre, fibre-reinforced matrix systems or any combination of them $[9,11]$. These materials were used, among others, in the production of rotor blades, load-bearing elements of the airframe structure, hulls, shields, etc. The materials were also used in the production of the rotor blades. $[1,4]$.

Composite materials are defined as materials having in their structure at least two components of different composition [6,3]: the first is the carrier material (e.g. carbon fibre, glass fibre, etc.) and the second is the bonding material (e.g. resin). The load-bearing material is primarily responsible for the strength parameters, but in most cases it shows high anisotropy [4]. This feature can be used to compose the directional strength of the composite material by arranging the matrix in selected directions in accordance with the load of the structure. Composites also have great possibilities to create structures having the required strength properties obtained by selecting appropriate 
components of the basic material, their mutual arrangement and the manner of their execution $[8,3]$. However, the manufacture and use in industry requires gaining knowledge about the influence of particular components and methods of manufacture on the final properties of the composite $[4,10]$. This is particularly important when new constituent materials appear. An example of such a material are symmetric ECC e461 and Interglas 02037 fabrics, which have lower tendency to creep and better mechanical properties than standard fabrics based on glass fibres $[2,4,6]$. The paper presents the results of compressive strength tests of a new composite material carried out with the use of manual lamination method based on the above fabrics.

\section{Description of the research}

\subsection{Object of research}

The object of research were composites based on symmetric fabric ECC e461 and symmetric fabric Interglas 02037 with resin MGS L285/H285 in different weave $\left(0 /+90\right.$ and $\left.+/-45^{\circ}\right)$. The basic technical parameters of the fabrics were described in Table 1 . They were laminated manually in the form of a single plate and hardened under a pressure plate in a vacuum bag with $-0.9 \mathrm{~atm}$. After curing, they were heated for 8 hours at $60^{\circ} \mathrm{C}$. Samples were cut from the plates to the dimensions required by the standard and then glass-epoxy composite covers were glued in, which protects the ends against crushing in the clamps of the testing machine. The specimens were $3 \mathrm{~mm}$ thick, $10 \mathrm{~mm}$ wide and $25 \mathrm{~mm}$ long, in accordance with ASTM D3410. Four batches of 5 specimens were made in each set.

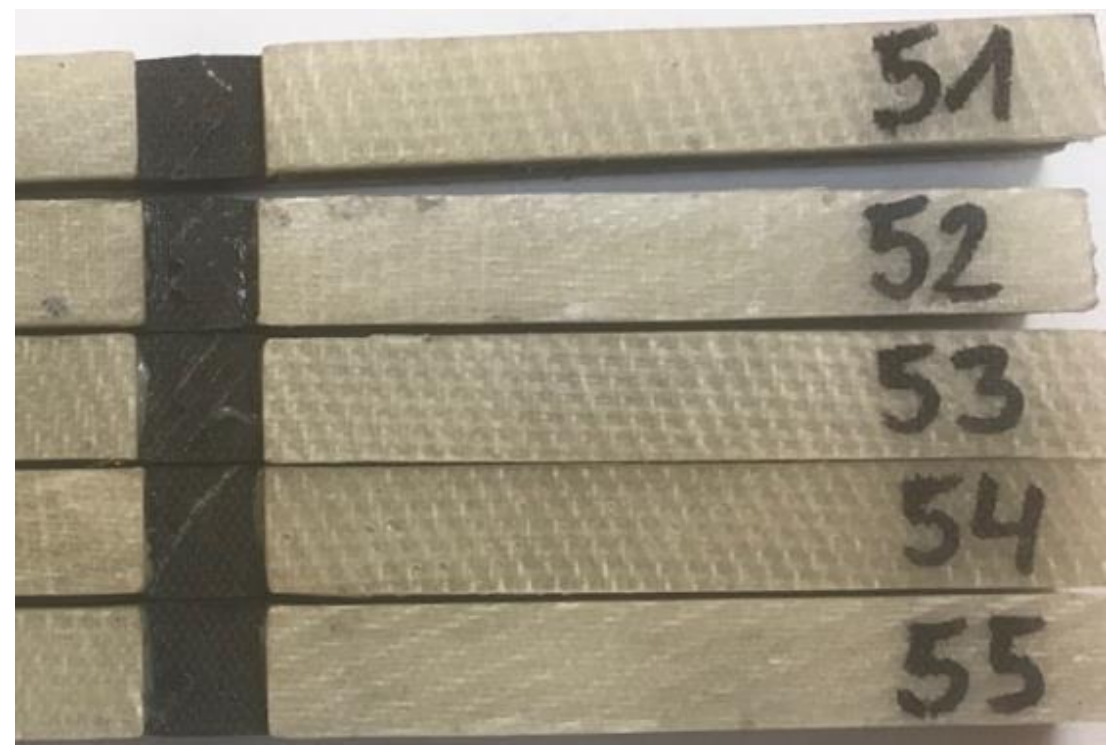

Fig.1 Composite samples before tests

The samples differed in the weave and the type of fabric used. Properly done:

(a) eight layers of ECC e461 symmetric fabric with MGS L285/H285 resin, using plain weave $\left(0 /+90^{\circ}\right)$ - samples from 51 to 55 ;

(b) eight layers of ECC e461 symmetric fabric with MGS L285/H285 resin, using +/$45^{\circ}$ weave - specimens from 61 to 65 ;

c) eight layers of reinforcement in the form of Interglas 02037 symmetrical fabric with MGS L285/H285 resin arranged in the direction 0/ $+90^{\circ}$ - samples marked 111-115;

d) eight layers of reinforcement in the form of Interglas 02037 symmetrical fabric with MGS L285/H285 resin arranged in the $+/-45^{\circ}$ direction - samples marked 121-125. 
Table 1. Material data for synthetic fabric ECC e461 and Interglas 02037

\begin{tabular}{|c|c|c|}
\hline Parameter & $\begin{array}{c}\text { Symmetrical fabric } \\
\text { ECC } \mathbf{~ 4 6 1 ~}\end{array}$ & $\begin{array}{c}\text { Interglas symmetrical } \\
\text { fabric 02037 }\end{array}$ \\
\hline $\begin{array}{c}\text { Textile sheet density } \\
{\left[\mathrm{g} / \mathrm{m}^{2}\right]}\end{array}$ & 80 & 47.5 \\
\hline Thickness $[\mathrm{mm}]$ & 0.19 & 0.22 \\
\hline Tensilestrength[MPa] & 117 & 88 \\
\hline $\begin{array}{c}\text { Bendingstrength[MPa } \\
]\end{array}$ & 197 & 156 \\
\hline Compressivestrength[ & 147 & $\begin{array}{c}\text { quickly saturated with } \\
\text { polyester and epoxy } \\
\text { MPa] }\end{array}$ \\
Features & $\begin{array}{c}\text { quickly saturated with } \\
\text { polyester and epoxy } \\
\text { resins }\end{array}$ & \\
\hline
\end{tabular}

\subsection{Research place}

Testing was performed on Instron 4485 press from ZwickRoell - Figure 2.
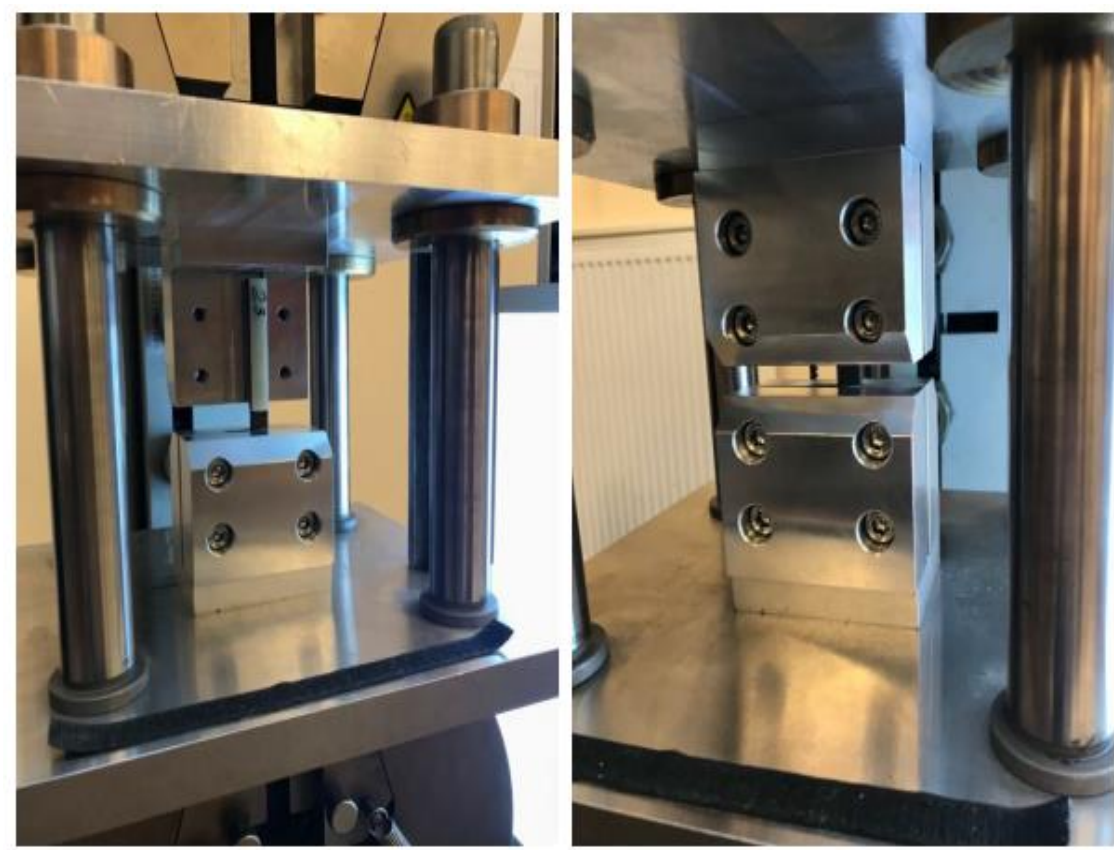

Figure 2. Instron 4485 ZwickRoell Test

The Instron press is an electro-mechanical device that allows for strength testing - Table 2. The tests are performed at a constant rate of deformation. Tensile and compression tests are recorded in an acquisition system that records both the degree of elongation/shortening and the force. The machine can be used to adjust the values of the following factors: force, elongation/shortening, time factor. 
Table 2. Instron 4485 pressparameters [12]

\begin{tabular}{|l|c|}
\hline \multicolumn{2}{|c|}{ PARAMETERS OF THE PRESS INSTRON 4485 } \\
\hline Maximum load & $200 \mathrm{kN}$ \\
\hline Workingspeed & $0,01-1500 \mathrm{~mm} / \mathrm{min}$ \\
\hline Workingspace & podwójna \\
\hline Measurementaccuracy & $\pm 0,5 \%$ \\
\hline Reductionmeasurements & do $40 \mathrm{~mm}$ \\
\hline Initialsamplelength & $10-100 \mathrm{~mm}$ \\
\hline Additionalinformation & possibility of examining round and flat \\
& samples \\
\hline
\end{tabular}

\subsection{Aim and scope of the research}

The aim of the research was to analyze the influence of composite structure and matrix material on the compressive strength of the obtained composite. The destructive tests were carried out on 4 batches of 5 pieces each, registering the change of load and deformation during compression. The scope of tests included 4 batches of different samples. The compression test was used to determine the stress-deformation characteristic, which allows to estimate the values of stresses that can damage or destroy the material.

\section{The results of the tests}

The results of the research are presented below. The dependence of the compressive force on the deformation for individual batches of samples is presented. Then, in the form of a table, the determined destructive stresses and the degree of strain during the destruction are presented.

Figure 3 shows the results of the 51-55 test specimens made of composite laminate with MGS L285/H285 resin reinforced with ECC e46 symmetrical fabric with $0 / 90^{\circ}$ weave to the axis of the specimen. The maximum force under load is 4.6 to $4.93 \mathrm{kN}$, which corresponds to a compression strength of 138 to $143 \mathrm{MPa}$ - Table 3. It ranged from 1.4 to $2.6 \mathrm{~mm}$, which corresponds to a relative shortening of 5.6 to $10.4 \%-8.3 \%$ on average. It should be noted that the compression process is characteristic of plastic materials with conventional yield strength. This limit occurs at loads ranging from 2.0 to $3.2 \mathrm{kN}$, which corresponds to a stress of 66 to $106 \mathrm{MPa}$. The compressive strength of the tested composite laminate is: $\mathrm{Rc}=143 \pm 3.4 \mathrm{MPa}$.

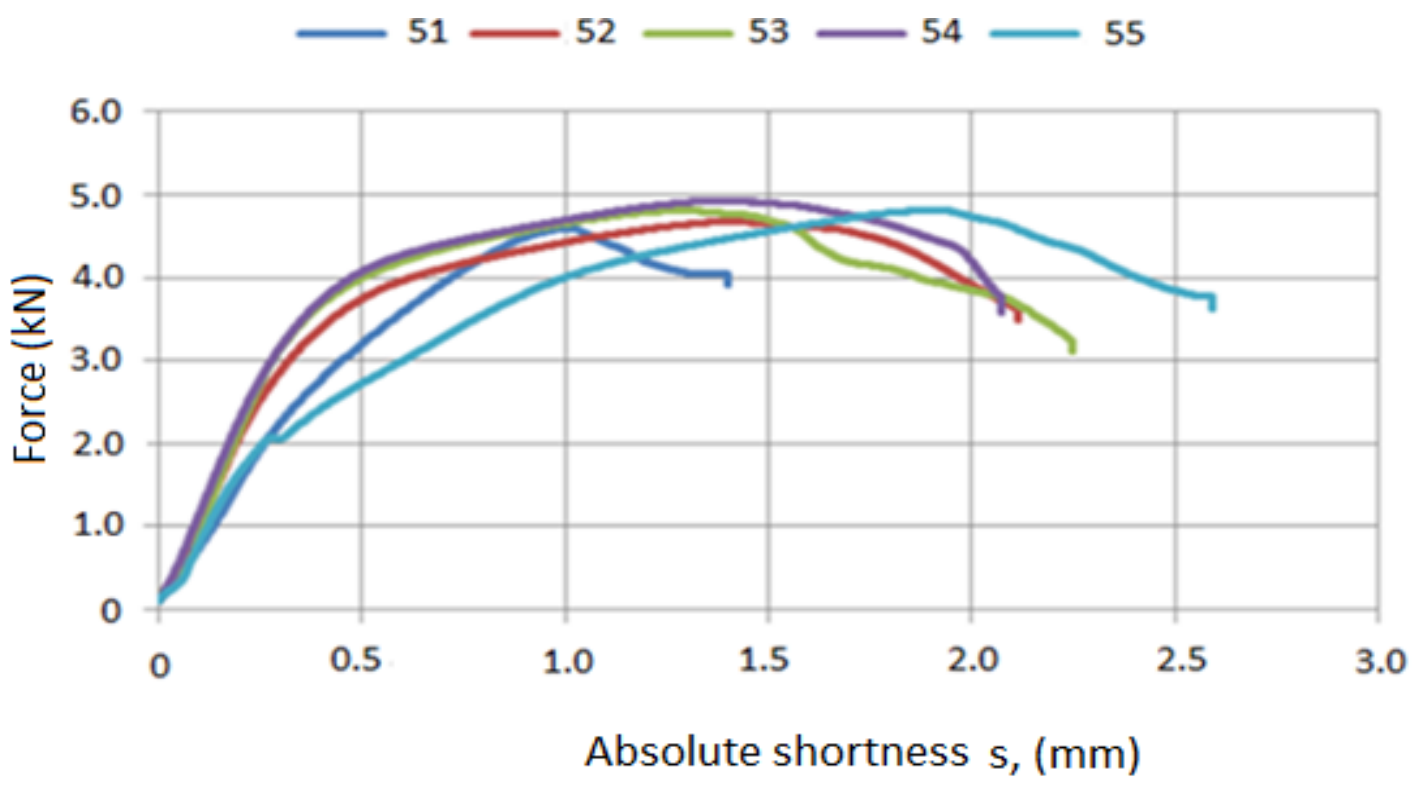

Figure 3. The dependence of the compressive force to the shortening of the relative composite laminate reinforced with the symmetrical fabric ECC e461, weave $0 / 90^{\circ}$. 
Table 3. Results of strength analysis for composite samples reinforced with symmetrical fabric ECC e461, weave $0 / 90^{\circ}$.

\begin{tabular}{|c|c|c|c|c|}
\hline Number & $\begin{array}{c}\text { Destructive force } \\
\mathbf{F}[\mathbf{k N}]\end{array}$ & $\begin{array}{c}\text { Compressive strength } \\
\mathbf{R c}[\mathbf{M P a}]\end{array}$ & $\begin{array}{c}\text { Absolute shortness } \\
\mathbf{s}[\mathbf{m m}]\end{array}$ & $\begin{array}{c}\text { Relative } \\
\text { shortness } \\
\mathbf{\Delta}[\%]\end{array}$ \\
\hline 51 & 4,672 & 141 & 1,40 & 5,6 \\
\hline 52 & 4,807 & 145 & 2,10 & 8,4 \\
\hline 53 & 4,928 & 145 & 2,25 & 9,0 \\
\hline 54 & 4,813 & 148 & 2,05 & 8,2 \\
\hline 55 & 4,592 & 138 & 2,60 & 10.4 \\
\hline Average: & 4,7626 & $\mathbf{1 4 3 , 3}$ & $\mathbf{2 , 0 8}$ & $\mathbf{8 , 3}$ \\
\hline
\end{tabular}

Figure 4 shows the results of testing 61 - 65 samples of composite laminate with MGS L285/H285 resin reinforced with ECC e461 symmetrical fabric with $+/-45^{\circ}$ weave. It can be observed that the absolute reduction was comparable for all samples and ranged from $1.55-1.85 \mathrm{~mm}$, it means $6.2-7.4 \%$ (mean 6.7\%). The maximum compression force is over $20 \mathrm{~N}$, which corresponds to 468 $\mathrm{MPa}$. Attention should be paid to the change in the shape of the characteristic curve. Damage to the specimen occurs at the highest load force and therefore the behaviour characteristic of brittle materials is present here. The compression strength ranges from 389 to $468 \mathrm{MPa}$ - Table 4. The compression strength of the tested composite laminate is as follows $\mathrm{Rc}=423 \pm 26.6 \mathrm{MPa}$.

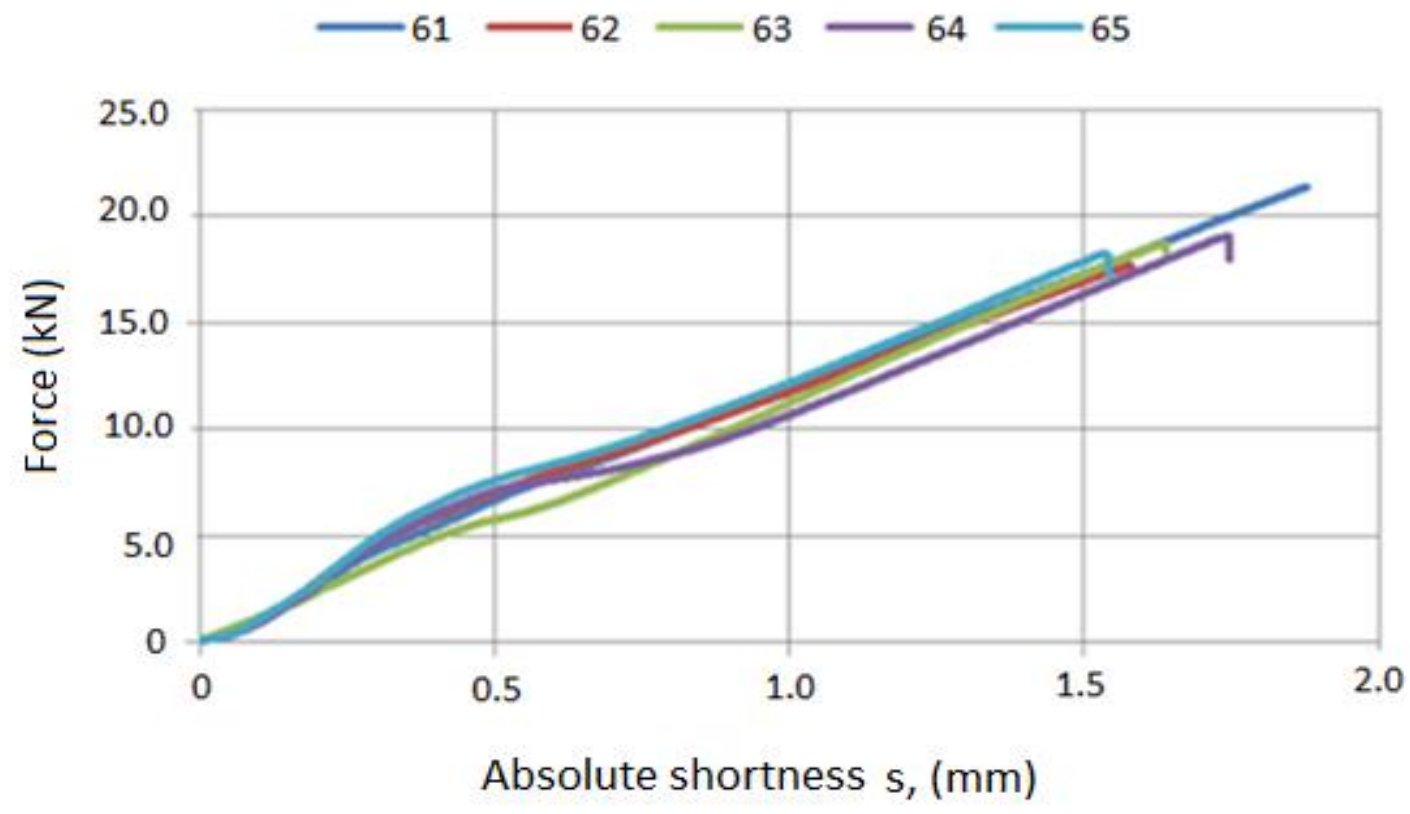

Figure 4. The dependence of the compressive force to the shortening of the relative composite laminate reinforced with the symmetrical fabric ECC e461, weave $+/-45^{\circ}$.

Table 4. Results of strength analysis for composite samples reinforced with symmetrical fabric ECC e461, weave $+/-45^{\circ}$.

\begin{tabular}{|c|c|c|c|c|}
\hline Number & $\begin{array}{c}\text { Destructive force } \\
\mathbf{F}[\mathbf{k N}]\end{array}$ & $\begin{array}{c}\text { Compressive strength } \\
\mathbf{R c}[\mathbf{M P a}]\end{array}$ & $\begin{array}{c}\text { Absolute shortness } \\
\mathbf{s}[\mathbf{m m}]\end{array}$ & $\begin{array}{c}\text { Relative } \\
\text { shortness } \\
\mathbf{\Delta}[\%]\end{array}$ \\
\hline 61 & 17,714 & 389 & 1,85 & 7,4 \\
\hline 62 & 18,740 & 431 & 1,60 & 6,4 \\
\hline 63 & 19,060 & 420 & 1,65 & 6,6 \\
\hline 64 & 18,229 & 405 & 1,75 & 7,0 \\
\hline 65 & 21,380 & 468 & 1,55 & 6,2 \\
\hline Average: & 19,0245 & $\mathbf{4 2 2 , 5}$ & $\mathbf{1 , 6 8}$ & $\mathbf{6 , 7}$ \\
\hline
\end{tabular}


Figure 5 shows the results of the tests of the samples of 111-115 specimens. The samples were made of composite laminate with MGS L285/H285 resin reinforced with Interglas 02037 symmetrical fabric of weave $0 / 90^{\circ}$. The graph shows that 111 and 112 samples were similarly shortened from 1.7 to $1.8 \mathrm{~mm}$, it means 6.8 to $7.2 \%$, while 113 also 114 and 115 samples were shorter from 1.2 to 1.32 $\mathrm{mm}$, i.e. 4.8 to $5.2 \%$ (on average $5.8 \%$ ). The maximum loading force of the specimen was $11.5 \mathrm{kN}$, which corresponds to the compressive strength of $320.8 \mathrm{MPa}$ - Table 5. The nature of the load changes is similar to that of the specimens of the series 5 - there is a noticeable conventional yield strength of about $6.0 \mathrm{kN}(200 \mathrm{MPa})$. The characteristic decrease in the final part of the test force in the case of specimens $111,113,114,115$ means that they have rapidly delaminated: $R c=321 \pm 27.6$ $\mathrm{MPa}$.

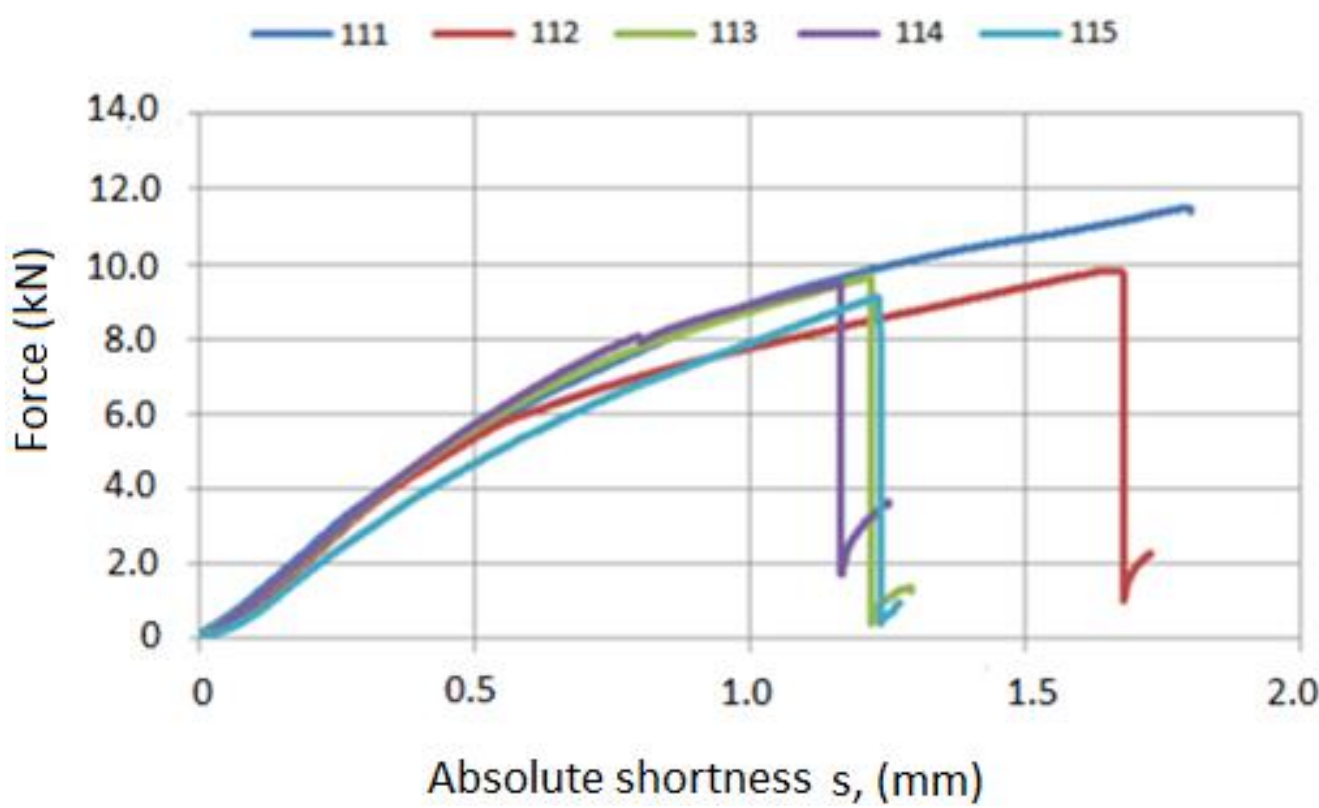

Figure 5. The dependence of the compressive force to the shortening of the relative composite laminate reinforced with the symmetrical fabric Interglas 02037 , weave $0 /+90^{\circ}$.

Table 5. Results of strength analysis for composite samples reinforced with symmetrical fabric Interglas 02037, weave $0 /+90^{\circ}$.

\begin{tabular}{|c|c|c|c|c|}
\hline Number & $\begin{array}{c}\text { Destructive force } \\
\mathbf{F}[\mathbf{k N}]\end{array}$ & $\begin{array}{c}\text { Compressive strength } \\
\text { Rc [MPa] }\end{array}$ & $\begin{array}{c}\text { Absolute shortness } \\
\mathbf{s}[\mathbf{m m}]\end{array}$ & $\begin{array}{c}\text { Relative } \\
\text { shortness } \\
\Delta[\mathbf{0}]\end{array}$ \\
\hline 111 & 9,809 & 324 & 1,80 & 7,2 \\
\hline 112 & 9,646 & 306 & 1,70 & 6,8 \\
\hline 113 & 9,476 & 302 & 1,30 & 5,2 \\
\hline 114 & 9,116 & 299 & 1,20 & 4,8 \\
\hline 115 & 11,510 & 373 & 1,32 & 5,2 \\
\hline Average: & 9,9113 & $\mathbf{3 2 0 , 8}$ & $\mathbf{1 , 4 6}$ & $\mathbf{5 , 8}$ \\
\hline
\end{tabular}

Figure 6 shows the results of tests of samples number 121-125. The samples were made of composite laminate with MGS L285/H285 resin reinforced with Interglas 02037 symmetrical fabric with $+/-45^{\circ}$ weave. It can be observed that one of the samples (122) was shorter, about $1.2 \mathrm{~mm}$ (4.8\%), while the other samples were shorter at the level of $2-2.2 \mathrm{~mm}$, it means $8.0-8.8 \%(7.5 \%$ on average). The loading force did not differ much for all the samples, and its mean value was $4 \mathrm{kN}$. The compressive strength was similar for all the samples, and the mean value was $142.4 \mathrm{MPa}-$ Table 6 . Also in this case, it can be seen that after exceeding the force of about $3.0-3.5 \mathrm{kN}$, the material undergoes plastic deformation until destruction. The compressive strength of the tested composite laminate is: $\mathrm{Rc}=142 \pm 2.7 \mathrm{MPa}$. 


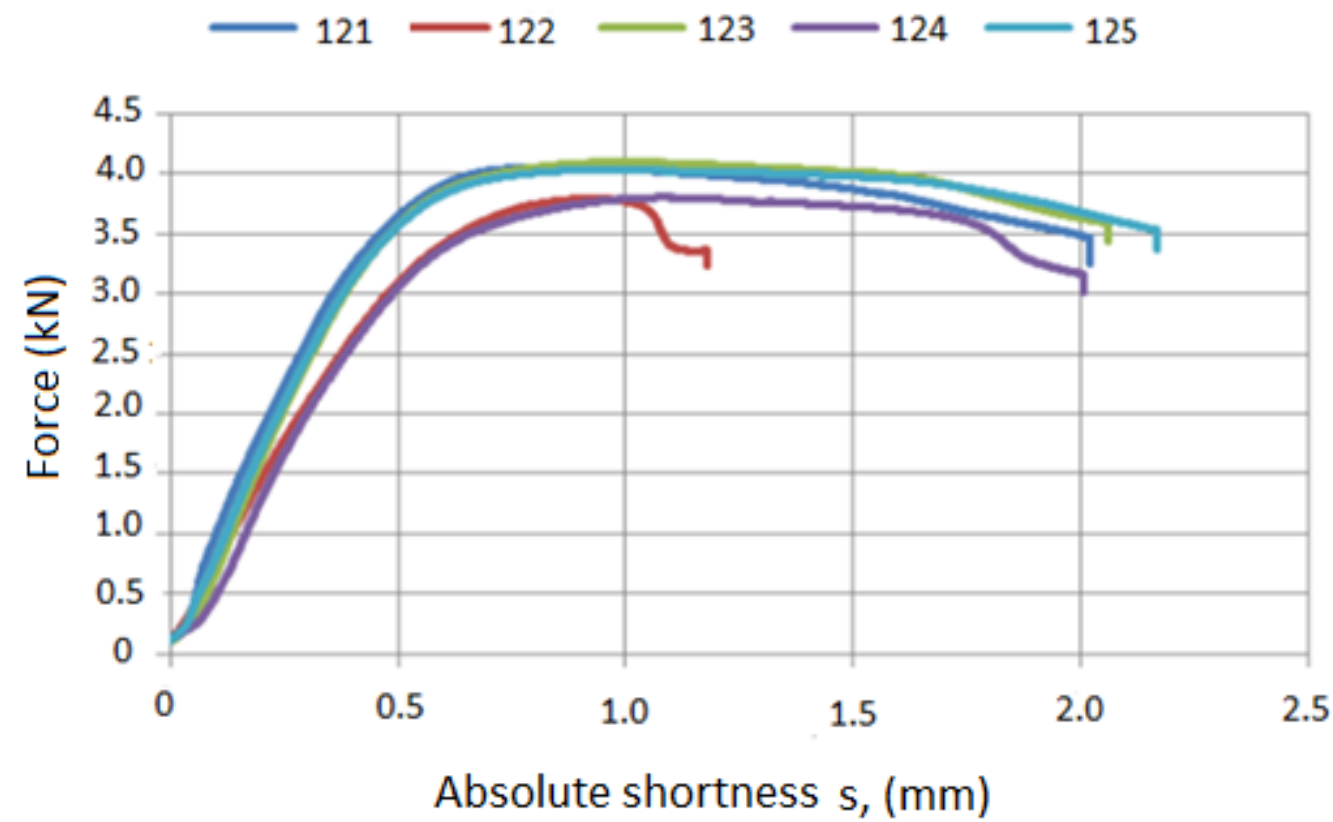

Figure 6. The dependence of the compressive force to the shortening of the relative composite laminate reinforced with the symmetrical fabric Interglas 02037 , weave $+/-45^{\circ}$.

Table 6. Results of strength analysis for composite samples reinforced with symmetrical fabric Interglas 02037 , weave $+/-$ $45^{\circ}$.

\begin{tabular}{|c|c|c|c|c|}
\hline Number & $\begin{array}{c}\text { Destructive force } \\
\text { F [kN] }\end{array}$ & $\begin{array}{c}\text { Compressive strength } \\
\text { Rc [MPa] }\end{array}$ & $\begin{array}{c}\text { Absolute shortness } \\
\mathbf{s}[\mathbf{m m}]\end{array}$ & $\begin{array}{c}\text { Relative } \\
\text { shortness } \\
\mathbf{\Delta l}[\%]\end{array}$ \\
\hline 121 & 3,792 & 137 & 2,02 & 8,0 \\
\hline 122 & 4,099 & 143 & 1,2 & 4,8 \\
\hline 123 & 3,803 & 143 & 2,05 & 8,2 \\
\hline 124 & 4,033 & 143 & 2,0 & 8,0 \\
\hline 125 & 4,050 & 146 & 2,2 & 8,8 \\
\hline Average: & 3,9556 & $\mathbf{1 4 2 , 4}$ & $\mathbf{1 , 6 5}$ & $\mathbf{7 , 5}$ \\
\hline
\end{tabular}

\section{Summary}

The compression test was carried out on 4 types of specimens, 5 in each series, with different weaves and reinforced fabrics. On the basis of compressive strength tests of the tested composite it was stated that:

1. The highest average compression strength was obtained in the case of the series marked 6 , which was reinforced with ECC e461 symmetric fabric and amounted to $442.5 \mathrm{MPa}$. The lowest compression strength in the series marked 12, reinforced with Interglas 02037 symmetric fabric and its value was $142.4 \mathrm{MPa}$.

2. The highest average shortening occurred in series 5 and amounted to $8.3 \%$, and the lowest in series 11 , where the value was $5.8 \%$.

3. When comparing a $90^{\circ}$ and $45^{\circ}$ weave, it can be seen that for a series of 5 and 6 specimens, the compression strength increases and the reduction decreases, meaning that the material is rigid and strong. For series 11 and 12 , the opposite is true, it means the compression strength decreases and the reduction increases, making the material more ductile. When considering the warp and comparing series 5 and 11, 11 have higher compression strength, while series 6 and 12 have higher compression strength. 
4. The reinforcement with ECC e461 symmetrical fabric in the series marked 5 (143.3 MPa) almost coincides with the strength of this material, whereas the series marked 6 significantly exceeds this value and amounts to $422.5 \mathrm{MPa}$. in the case of reinforcement with the symmetric fabric Interglas02037 a similar situation can be observed, because the series with the designation 11 has an average compression strength of $320.8 \mathrm{MPa}$ and the value read from Table (156 MPa), while the second series with the designation 12 has an average strength of $142.4 \mathrm{MPa}$. In the case of materials with a weave of $90^{\circ}$ from series 5 and 11 , a large standard deviation of the determined compressive strength can be observed. This means that the material has a large production spread.

5 . When analysing the nature of the stress variation during deformation, it can be concluded that Series 6 and 12 material behaves typically as brittle material and therefore increases the stress to failure. In the case of Series 5 and 11 materials, delamination has occurred, i.e. delamination, which reduces the stress at further shortening. A similarity to the yield point can be observed.

To sum up, it can be stated that the best material of the 6 series (composite laminate with MGS L285/H285 resin reinforced with ECC e461 symmetrical fabric with $+/-45^{\circ}$ weave) proved to be the best. This material has the highest compressive strength of $422.5 \mathrm{MPa}$ and the lowest standard deviation. Moreover, it has been shortened relatively slightly in comparison to other series (6.7\%).

\section{References}

[1] J. D.Buckley, D. Edie Dan, Carbon-Carbon Materials and Composites. William Andrew pp. $12-$ 181993.

[2] T.D.Burchell, Carbon Materials for Advances Technologies, Elsevier Science pp. 1 - 321999.

[3] Y. Chen, Engineering Energy Aluminium Conductor Composite Core and Its Application, Academic Press pp. 42 - 452019.

[4] H.Zvi, C.T Herakovich,Mechanics of Composite Materials, Pergamon pp. 13 - 281983.

[5] J. F.Rabek, Współczesna wiedza o polimerach. Tom I. Warszawa: Wyd. Naukowe PWN pp. 1 - 27 2008.

[6] J. Garbarski, Materiały i kompozyty niemetalowe. Warszawa: Wyd. Politechniki Warszawskiej, pp. 12- 172001.

[7] H.Dąbrowski, Wytrzymałość polimerowych kompozytów włóknistych, Oficyna Wyd. Politechniki Wrocławskiej pp. 20 - 212002.

[8] W. Królikowski, Polimerowe kompozyty konstrukcyjne. Warszawa: Wyd. Naukowe PWN, pp. 14 302012.

[9] K.Szlezyngier, Z.Brzozowski, Tworzywa sztuczne. Tom II. Warszawa: Wyd. Oświatowe FOSZE, pp. 14 - 172013.

[10] A. Bełzowski, Podstawowe wiadomości o próbach wytrzymałości materiałów kompozytowych, Politechnika Wrocławska, Wrocław, pp. 1- 182007.

[11] http://www.tooling.milar.pl/zelkoty-i-zywice-do-laminowania/epoksydowe-zywice-dolaminowania/ [Accessed: 05 - Apr - 2019].

[12] https://www.instron.us/en-us/products/testing-accessories/load-frame-accessories/loadframesupport-tables-bases/2910-064 [Accessed: 09 - Mar - 2019]. 